\title{
Encontro em carne-viva
}

Matheus Araujo dos Santos

UFRJ/UFBA

\section{Resumo}

A perspectiva do encontro nos permite atentar para as possibilidades de criação artística que se direcionam à multiplicidade e à diferença. A partir dos trabalhos produzidos conjuntamente por Sara Panamby e Filipe Espindola Meu Corpo É Meu Protesto, Compassos do Ocaso, A Sagração de Urubutsin e Pérolas aos Porcos - este texto apresenta alguns comentários e reflexôes sobre as potências efetuadas e relaçôes compostas entre eles.

Palavras-chave: Encontro; performance; Sara Panamby; Filipe Espindola.

\begin{abstract}
The prospect of the encounter allows us to pay attention to the artistic creation of possibilities that are directed to the multiplicity and difference. From the works jointly produced by Sara Panamby and Filipe Espindola Meu Corpo É Meu Protesto, Compassos do Ocaso, A Sagração de Urubutsin e Pérolas aos Porcos - this paper presents some comments and reflections made on the potentia and composite relations between them.
\end{abstract}

Keywords: Encounter; Performance; Sara Panamby; Filipe Espindola. 
1. DELEUZE, Gilles. En medio de Spinoza, 2013.
Este texto trata do encontro entre Sara Panamby e Filipe Espindola. Mais do que uma narrativa interessada na descrição do encontro em si, busca-se aqui perceber as potências efetuadas nas diversas vezes em que ele se dá. No momento em que passam a produzir coletivamente, parece proveitoso observar como singularidades se conectam engendrando processos de criação de um corpo maior. Nem um, nem outro; corpos mais complexos que se fazem e desfazem a cada ação.

$\mathrm{O}$ afeto/encontro, como tomado por Gilles Deleuze ${ }^{1}$ a partir da sua leitura da obra de Baruch Spinoza, pode ser um lugar estratégico para pensarmos a nossa relação com o outro e as possibilidades de uma ética como modo de vida. Nesta perspectiva, o que vem à tona são as trajetórias que possibilitam a composição de determinadas relações, afetos/encontros contidos no núcleo de cada movimento ou açáo.

A partir de alguns trabalhos de Sara e Filipe, penso no modo como os gestos artísticos frutos deste encontro apontam para a construção de corpos que reclamam multiplicidade. Seja pela união das suas singularidades ou pela abertura às experiências coletivas de marginalidade e abjeção invocadas em suas performances, há sempre uma dimensão do comum ao qual somos lançados quando presenciamos suas açóes. Pergunto-me, em resumo, que relaçôes são capazes de compor estas singularidades. Quais potências são efetuadas a partir deste encontro? Que corpos são criados quando a individualidade se abre ao outro?

Proponho uma aproximaçáo da performance enquanto linguagem a partir de sugestóes de Eleonora Fabiáo sobre sua força e potência. Nos primeiros dois tópicos recorro aos trabalhos Meu Corpo É Meu Protesto, Compassos do Ocaso e A Sagração de Urubutsin. Minha aproximação destes trabalhos se dá por meio de relatos, fotografias e vídeos, uma vez que náo estive presente nas únicas vezes em que foram apresentados. Em um último tópico, narro minha experiência na primeira vez em que os vi performando juntos Pérolas aos Porcos.

Força

Começo a partir de sugestôes de Eleonora Fabiáo sobre a performance, quando ela escreve:

Esta é, a meu ver, a força da performance: turbinar a relação do cidadáo com a polis; do agente histórico com seu contexto; do vivente com o tempo, o espaço, o corpo, o outro, o consigo. Esta é a potência da performance: des-habituar, desmecanizar, escovar à contra-pêlo. Trata-se de 
buscar maneiras alternativas de lidar com o estabelecido, de experimentar estados psicofísicos alterados, de criar situações que disseminam dissonâncias diversas: dissonâncias de ordem econômica, emocional, biológica, ideológica, psicológica, espiritual, identitária, sexual, política, estética, social, racial...2

Tomarei estas duas proposiçóes da autora como modos de aproximaçáo do trabalho de Sara e Filipe. Neste primeiro momento trato de pensá-lo a partir da sua força para, em seguida, voltar-me às suas potências.

A força da performance consistiria, segundo esta perspectiva, no processo de "turbinar relaçôes". Se outras linguagens - penso especialmente na escultura e na pintura - permitem abordagens que privilegiem a obra de arte enquanto objeto, a performance parece não nos deixar esta alternativa, uma vez que ela impóe, precisamente, o seu aspecto relacional.

Embora náo seja um interesse exclusivo da linguagem, movimentos intersubjetivos parecem estar no seu cerne. É justamente esta noção de relacionalidade que Nicolas Bourriaud associa à prática artística contemporânea, que consistiria na criação de "uma forma capaz de 'durar', fazendo com que entidades heterogêneas se encontrem num plano coerente para produzir uma relação com o mundo"3.

Ao opor comunicação e arte, Bourriaud ${ }^{4}$ acredita que a primeira tem por objetivo encerrar "os contatos humanos dentro de espaços de controle que decompóem o vínculo social em elementos distintos", enquanto a segunda executaria um movimento contrário, tentando "efetuar ligaçôes modestas, abrir passagens obstruídas, pôr em contato níveis de realidade apartados”.

Não me detenho na sua primeira afirmação sobre comunicação (que tomo, neste caso, como informação), mas para me aproximar do trabalho de Sara e Filipe - e também da performance como linguagem artística - creio que suas sugestóes sobre arte e relacionalidade podem nos ajudar por nos levar em direção a problemas como contato, ligação e abertura; possibilitando-nos pensar a arte performática como uma espécie de interstício social marcado pela composição de vínculos e critérios de coexistência 5 .

São estas características que me levam a tomar o trabalho dos dois a partir da questão do encontro. Antes do encontro entre público-interlocutor e artistas, há o encontro entre os artistas mesmo, entre Sara e Filipe. Creio que pensar a força deste primeiro encontro nos permite uma aproximação mais interessante das ações e afetos que surgem a partir dele.

Filipe é artista plástico de formação e colecionador por uma quase-obsessão. Conviver com ele é estar imerso em séries e repetiçóes (e, portanto, diferenças): quadrinhos, bonecos, unhas,
2. FABIÃO, Eleonora.

"Performance e teatro: poéticas e políticas da cena contemporânea, 2009, p. 235-246.

3. BOURRIAUD, Nicolas. Estética Relacional, 2009, p.49.

4. Ibidem, p.11.

5. Ibidem, p.22 e p.151. 
revistas pornô, garrafas pet, manequins, selos e assim por diante. Boa parte da sua pesquisa e produção é influenciada pelas técnicas de colagem e assemblage, sendo composta majoritariamente por quadros e livros em que ele constrói o seu universo poético a partir de materiais colecionados, muitas vezes reciclados, encontrados a esmo ou que, ao contrário, tenham para ele uma grande carga afetiva, como prontuários médicos de uma internação ou bonecos playmobil.

Ao mesmo tempo, a modificação corporal é algo igualmente importante. Além dos seus próprios furos, alargamentos e tatuagens - que são numerosos -, ele atua como piercer e também como tatuador. Sara e Filipe se conheceram quando ela, na intenção de realizar uma performance ritual, contratou-o para um trabalho de suspensão corporal; Meu Corpo É Meu Protesto (2009).

Arriscaria dizer que Sara é uma artista-do-corpo. Seu processo de criação é cotidiano. A todo momento uma nova roupa, maquiagem, cabelo, gíria. Seu corpo parece estar sempre em jogo, exaltando infinitas possibilidades de ser. A ação performática como composição de imagens e conexóes entre formas heterogêneas: La Pocha Nostra way-of-life. Sara é uma índia-ciborgue; um corpo em constante mutação.

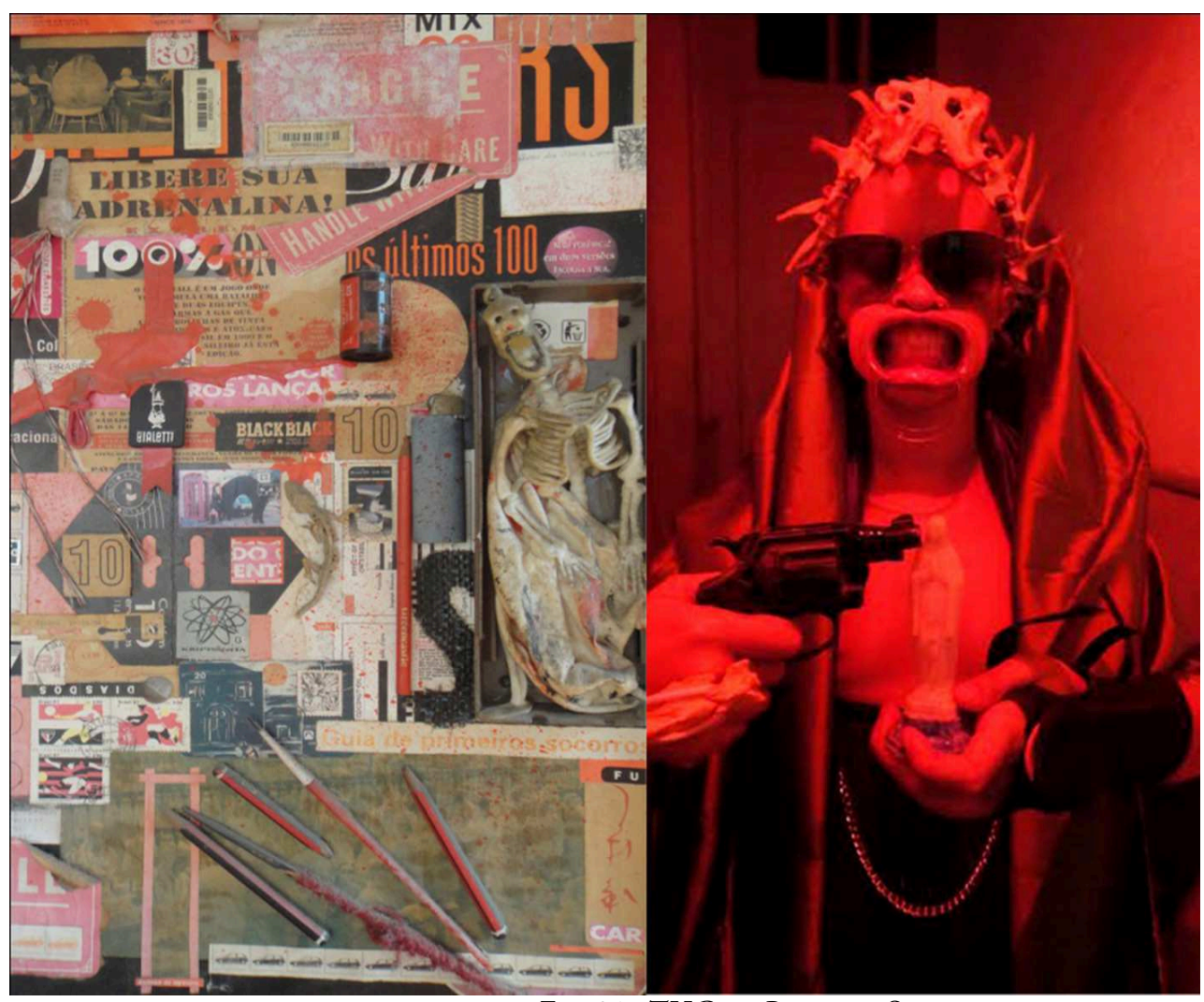

Fig. 01: THCem: Primeiros Socorros,

Filipe Espindola, 1997 (detalhe) [esquerda].

Nossa Senhora de Escarnificina, Sara Panamby, 2012 [direita]. 
O processo de construção performática destes corpos se cruza com os métodos de colagem e assemblage utilizados por Filipe: o recolhimento de partes heterogêneas para a criaçáo de um corpo mais complexo, o reaproveitamento de substâncias (reciclagem) e a escolha afetiva dos materiais são alguns destes pontos de conexão. Com o tempo, Sara inicia a produção de colagens, experimentando as artes plásticas e Filipe, por sua vez, passa a utilizar o seu corpo de modo mais veemente a cada ação que performam juntos. Há uma troca intensa e produtiva entre os dois. As influências e conexôes que efetuam são muitas e de fundamental importância para a continuidade dos seus trabalhos que, cada vez mais, apresentam-se como uma produção coletiva, da criação à ação.

Meu Corpo é Meu Protesto é a primeira performance de Sara em que ela dispóe o seu corpo à provaçóes mais extremas. Ainda que a questão do risco estivesse presente em seus trabalhos anteriores, em especial os desenvolvidos em parceria com o coletivo Meninasjoão, é neste momento que a perfuração corporal se torna central na ação. Com dois ganchos atravessando suas costas, Sara é elevada enquanto expurga seus demônios em gritos de êxtase.
6. PANAMBY, Sara. O Corpolimite, 2013.

7. GÓMEZ-PEÑA, Guillermo.

"En defensa del arte del performance". Horizontes antropológicos, 2005, p. 212.

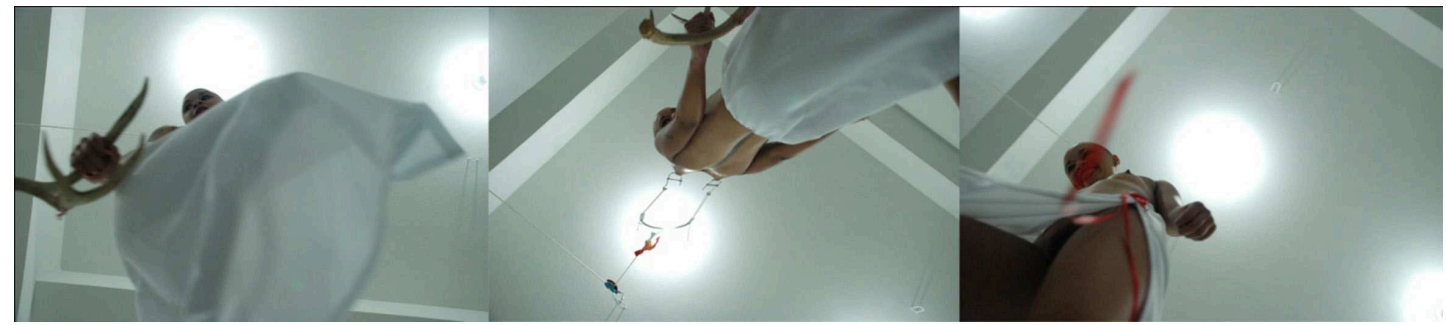

Fig. 02: Meu Corpo É Meu Protesto, 2009. Foto: Clara Antoniazzi

"A pesquisa Corpolimite parte do discurso de onde a fisicalidade e experiência informe do corpo que atravessa camadas, dos rituais de passagem às políticas urbanas, cria complexidades e zonas desestabilizantes que revelam saberes via percepção e sentidos através da experiência poética em carne-viva"'. As palavras são da própria Sara, que com suas açôes performáticas investe também em investigações teóricas. Aliás, temos aí uma outra tentativa de aproximação da linguagem: "el performance es una forma de teoría incorporada al cuerpo...”

O Corpolimite pelo qual busca a artista tem um grande momento de emersáo quando ela e Filipe se encontram - a suspensão funciona aqui como uma metáfora/ação perfeita. Enquanto Sara explora as potências pulsantes do seu corpo, Filipe intervém, modifica e rearranja posiçóes e formas a partir da sua experiência na área de modificação corporal. Ao mesmo tempo, como sinalizei, ocorre o movimento inverso, no qual o corpo dele é cada vez mais exigido presente como força a ser explorada - no sentido de também se pôr em risco. As relaçóes compostas 
8. Participaram com eles as performeras Michelle Mattiuzzi, Renata Borges e o músico Petrônio Sales. entre os dois os pressionam mutuamente em direção a disposiçôes e conformaçôes corporais que possivelmente não seriam tão fáceis de se alcançar individualmente.

Uma outra aproximação das suas individualidades que nos ajuda a pensar nos trabalhos desenvolvidos a dois diz respeito a uma inclinação a questôes ritualísticas ligadas, principalmente, a comunidades ancestrais. A modificação corporal é tomada tanto por um quanto por outro como processos de inscriçóes rituais, nos quais o corpo se coloca como substância central em cerimônias de passagem.

A ritualização da performance não tem consequências apenas temáticas, mas também diz respeito aos possíveis modos de lidar com a linguagem, no sentido mais pragmático de como realizar uma ação. Lembro de Compassos do Ocaso, trabalho realizado pelos dois como uma homenagem póstuma à avó de Sara. No centro de São Paulo, Sara e Filipe são suspensos enquanto choram a morte da matriarca Rita. A ação tem como inspiração primordial o Kuarup, ritual indígena proveniente do alto Xingu, cuja função é a de prestar homenagem aos mortos mais notáveis da comunidade. As consequências desta aproximação ritualística já estão presentes no momento de planejamento da ação, quando Sara, Filipe e amigos que também participaram da performance ${ }^{8}$ se reunem em um processo de imersão que durou sete dias.

A vivência coletiva teve como atribuição a pesquisa, a experimentação e a confecção de trajes, tintas, músicas e objetos que foram utilizados na ação. Para além deste objetivo prático, o que acontece é a troca de experiências através do convívio intenso. Assim como o Kuarup, trata-se de uma ação comunitária dedicada a alguém cuja falta é sentida. As dimensóes afetivas e biográficas se entrecruzam invariavelmente com o trabalho artístico; arte e vida estão, nesse momento, fatalmente intrincadas.

Neste período de imersão, eles encontraram pela casa fitas K7 abandonadas e puderam escutar a avó de Sara em conversas até então esquecidas. Este material é incorporado à performance e, no momento da ação, enquanto andam pela cidade arrastando objetos sustentados pelos ganchos em suas costas, ouvem a voz de Rita, por quem as lágrimas caem.

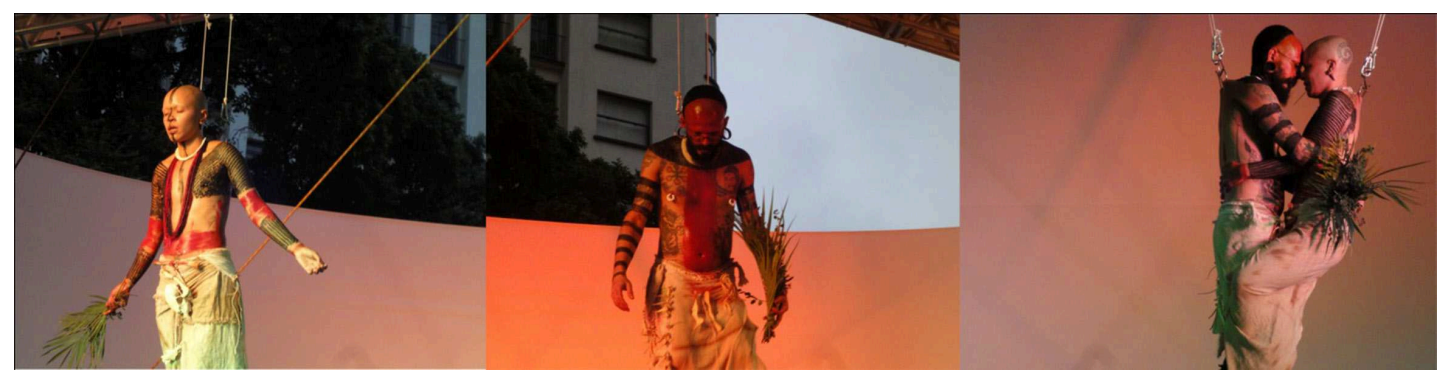

Fig. 03: Compassos do Ocaso. Foto: Lúcia Rosa 
Ao invocar Compassos do Ocaso, quero chamar a atenção para o fato de que esta apreensão ritualística do trabalho nos permite pensar a performance para além (ou para aquém) da ação em si. Ela começa no momento mesmo da imersão, tendo início no instante em que os artistas se encontram e convivem na intençáo de produzir a partir da experiência comum'.

A atenção aos rituais e existências ancestrais se dá a ver nas próprias marcas que Sara e Filipe levam no corpo. Da primeira vez que saímos juntos eu, ainda não acostumado, cheguei a me assustar com a quantidade de pessoas que se aproximavam em busca de algum contato. "Você é lésbica?”; "Dói muito?”; "Mas como você teve coragem?"; "Posso pegar?", foram algumas das perguntas que lembro ter ouvido naquele dia. Hoje elas me levam a pensar em como a presença dos seus corpos tem a capacidade de afetar o ambiente e as pessoas ao redor; em como o contato com eles tem a capacidade de engendrar açóes e reaçóes das mais diversas; da atração à repulsa, parece sempre haver algo a sentir.

Fakir Musafar, uma espécie de deus vivo da modificação corporal, fala do conceito de primitivos modernos ${ }^{10}$ para se dirigir a certas existências que, mesmo imersas em um mundo capitalista, voltam-se a práticas e experiências de culturas ancestrais. Creio poder me referir a Sara e Filipe como exemplos destes modos de ser e creio também ser isso que, em um primeiro momento, torna a presença deles táo forte. Seus corpos se apresentam na contradição. Temporalidades se cruzam gerando uma série de perturbaçóes em diversas ordens; da sexual à econômica. Os primitivos modernos contribuem para o movimento de negação da oposição entre cultura e barbárie; magia e técnica. São corpos fronteiriços, interstícios sociais em si, cuja presença parece fundir uma série de saberes e práticas que se querem divergentes.

Em Dances Sacred and Profane ${ }^{11}$, um dos poucos registros documentais sobre Musafar, vemos ele demonstrar esta busca pelas possibilidades do corpo através de experiências místicas que envolvem transes, êxtases e modificaçóes corporais. O corpo é tomado como força e como potências e serem efetuadas.

Creio que estas observaçóes se fazem propícias para apontarmos uma outra característica da performance como linguagem artística, o da presença em detrimento da representação. Não me demoro exaustivamente na questão, no entanto a perspectiva da presença é extremamente útil diante da nossa proposição de pensar a linguagem performática a partir do paradigma do encontro.
9. PANAMBY, Sara.

"Compassos do Ocaso: An

Experiential Re-telling”, 2013b.

10. MUSAFAR, Fakir. Modern

Primitives, 1989.

11. Documentário de 1985

dirigido por Dan e Mark Jury. 
12. GUMBRECHT, Hans Ulrich. Produção de Presença, 2011.

13. FABIÃO, Eleonora.

"Performance e teatro: poéticas e políticas da cena contemporânea", 2009, p.235246.
O modo mais simples e corriqueiro de apresentar este problema é contrapor a performance ao teatro, especialmente quando se pretende distinguí-la de outras linguagens. Ou, então, de apontar como alguns movimentos teatrais já se direcionavam a questôes essenciais à performance, sendo talvez o melhor exemplo o teatro da crueldade artaudiano.

Aceito o maior dos senso comum: não se trata de representar um personagem, mas de apresentar (ou criar) um corpo-ação que vale por sua força e intensidade. Neste sentido, a performance parece estar no mesmo fluxo do movimento definido por Hans Ulrich Gumbretch em termos de uma volta à sensação e à presença que, segundo ele, haveriam sido postas de lado em benefício de uma "cultura do sentido"12.

\section{Potência}

Se a força da performance está na composição de relaçôes, a sua potência estaria na disseminação de dissonância ${ }^{13}$. Esta perspectiva do performero como causador do dissenso me parece potente para pensar o encontro que aqui nos interessa. O primeiro dos motivos para que eu faça esta afirmação é saber que ambos se colocam nesta posição. E não só eles. Em meus encontros com artistas da performance noto como há entre eles uma clara urgência política que parece ser indiscernível da própria questão estética. Não defendo aqui que a performance seja uma linguagem "mais política" que outras, mas que muitos perfomeros, ao menos os com que tive contato, tomam o seu trabalho como radicalmente político. E é sobre este sentimento construído coletivamente que me atenho.

No dia 17 de junho de 2014, enquanto escrevo este texto, recebo o telefonema de uma amiga que me conta que Filipe, Sara e outras três artistas haviam sido detidas pela Polícia Militar do Estado do Rio de Janeiro, na Candelária, por "utilizarem máscaras" (eles tinham seus rostos pintados) e estarem em "atitude de manifestação", nas palavras de um dos PMs. Tratava-se de uma ação de deriva poética que foi interrompida por ter sido tomada como uma ameaça ao sistema de segurança da Copa da FIFA, que ocorria neste período.

Suspeito que a "atitude de manifestação", como conceituou o policial, diga respeito à produçáo de dissonância a que se refere Fabião. Na delegacia, a falta de evidências sobre qualquer crime 
cometido levou os responsáveis a fichá-los como "caso atípico". Trata-se, sem dúvida, de uma destas potências de desabituação e desmecanização da performance.

Neste momento as palavras de Guillermo Gómez-Peña podem nos ser úteis para pensar este fenômeno. No seu Manifiesto en defensa del arte del performance ele discute a atração da performance em direçâo às existências singulares e àquelas consideradas periféricas. Trata-se, de acordo com ele, de uma relação profunda entre o performero e as vidas marginais:

\begin{abstract}
Vemos nuestro futuro probable reflejado en los ojos de los indigentes, de los pobres, los desempleados, los enfermos, y los inmigrantes recién llegados. Nuestro mundo se traslapa con el de ellos. A menudo nos sentimos atraídos hacia aquellos que apenas sobreviven en las peligrosas esquinas de la sociedad: prostitutas, borrachines, lunáticos y prisioneros son nuestros hermanos y hermanas espirituales. ${ }^{14}$
\end{abstract}

Os traços desta perspectiva no trabalho de Filipe e Sara são muitos. Como mencionei anteriormente, os corpos dos dois já apresentam questóes de diversas ordens a partir da própria presença. Em suas açóes podemos identificar referências à vida indígena ou às questóes de gênero e sexualidade, por exemplo, a partir de signos relacionados às suas vestimentas ou modificaçóes genitais expostas em cena. No entanto, gostaria de pensar esta atração a que se refere Gómez-Peña de um outro ponto de vista, que diz respeito ao corpolimite e à experiência poética em carne-viva a que se refere Sara. Tomo como ponto de partida para as reflexóes seguintes $A$ Sagração de Urubutsin, ação executada como parte da sua pesquisa e defesa no mestrado.

Numa grande sala onde expóe trabalhos de assemblage desenvolvidos no decorrer da sua pesquisa, Sara adentra completamente nua. Seu corpo é adornado pelas marcas que carrega; tatuagens, piercings e alargadores. Ela se dirige a um banco e, sentada, começa a tocar didgeridoo por um tempo extenso. $\mathrm{O}$ instrumento aborígene produz som a partir da vibraçáo do ar. Trata-se de uma experimentação de frequências e intensidades. Um primeiro chamado a viver a ação mais pela sua sensação do que por qualquer tentativa de interpretação. Um ato de abertura do trabalho, que apresenta um intenso devir-xamânico devido também ao seu caráter cerimonial como rito de passagem.

Enquanto ela toca, Filipe se aproxima usando luvas e botas negras de salto alto. A cabeça raspada está completamente branca, com exceção dos lábios pintados por um batom vermelho; uma gueixa-sadomasoquista. Aos poucos ele perfura a pele de
14. GÓMEZ-PEÑA, Guillermo. "En defensa del arte del performance", 2005, p. 210. 
Sara. Às extremidades das agulhas estáo coladas penas de urubu. O movimento de perfuração dura cerca de uma hora, na qual ela tem seus braços, pernas, costas, boca e cabeça perfurados por 77 agulhas.

Sara vira urubu. Filipe se afasta. Aos poucos ela levanta e experimenta, em pé, o seu novo corpo, começando após algum tempo uma série de movimentos lentos que têm como função tirar, uma a uma, as agulhas que atravessam a sua pele. A cada agulha retirada, Filipe lhe estende a mão e as enfia em um coração de boi servido em um agdá colocado a sua frente. A cada agulha retirada, um traço de sangue que escorre por sua pele. A coroa formada por sete penas-agulhas são as que mais sangram quando apartadas do seu corpo recém-adquirido.

Sara experimenta o fluxo do sangue que escorre, deita-se em um pano branco deixando nele a sua escrita sanguínea para, em um último movimento, levantar-se, passar a mão pelo rosto ensanguentado e marcar com a palma da mão a última página do livro de colagens que havia entregue à banca como parte da sua produção final.

Ao descrever esta performance percebo a quantidade imensa de dissonâncias disseminadas. A ação pode ser tomada por inúmeras perspectivas, uma vez que invoca problemas das mais diversas ordens; impossível me concentrar em todos eles agora. Proponho uma aproximação interessada na sua força e potência e também no direcionamento às existências marginais e à formação de um comum que sugiro fazer parte desta urgência política à qual me refiro.

Para tanto, parece ser proveitoso pensar por um momento na perfuração corporal e no uso do sangue em cena. Seguramente para muitos a reação é de horror. Acompanhar a carne sendo perfurada ou presenciar o sangue verter é intolerável para os que preferem deixar o local onde ocorrem as açôes. Outros olham hipnotizados, completamente atraídos. A reação de choro também é comum.

A poética em carne-viva se constitui nestas ações a partir de encontros intensos da ordem da sensação. Apesar da materialidade do sangue, há uma questão de força que nos faz pensar em estratégias vanguardistas de choque. Não obstante, recuso-me a tomar as açôes aqui descritas a partir de uma estética do efeito por não crer que seu caráter extremo diga respeito apenas a tentativas de provocar o horror através do excesso. 

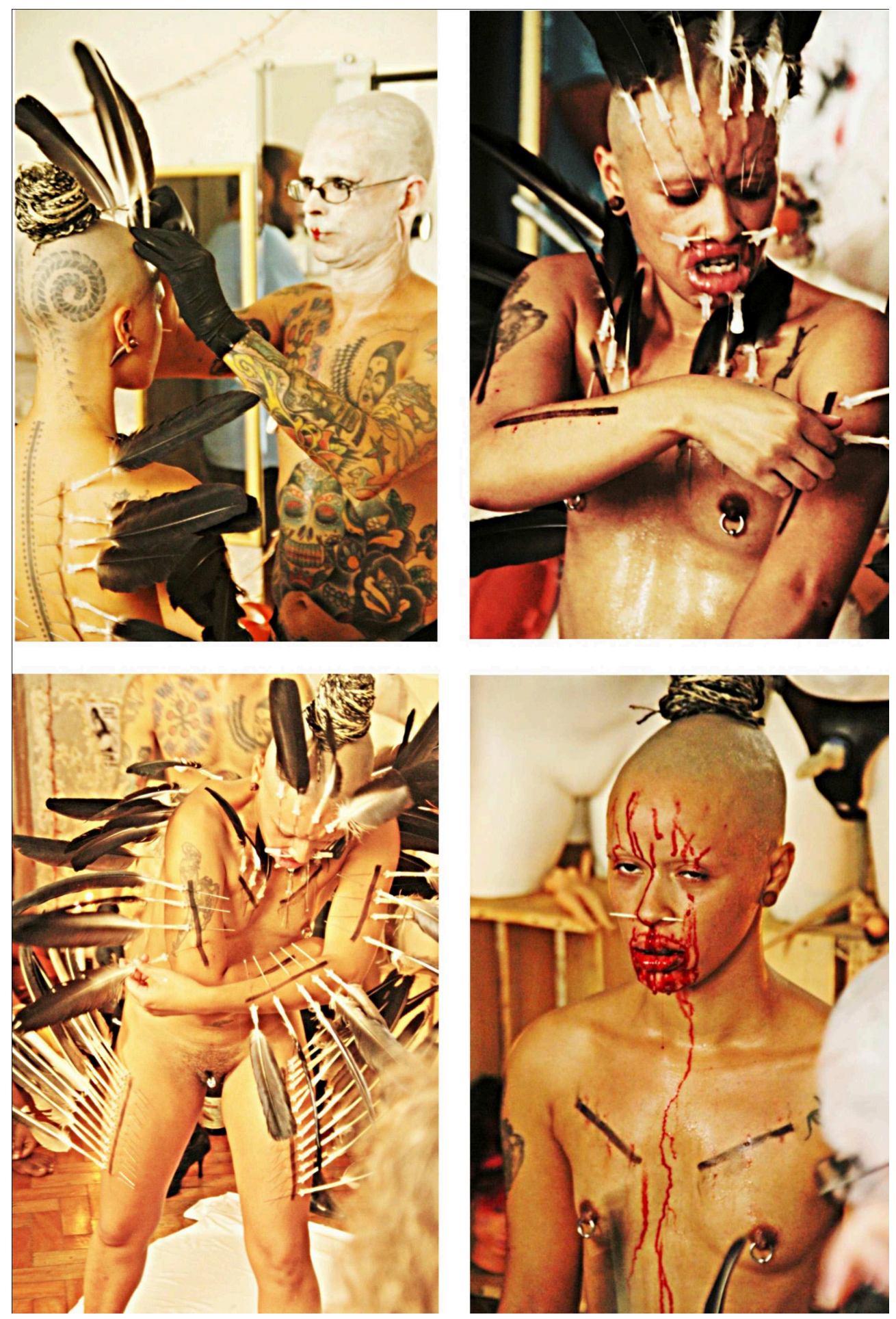

Fig. 04: A Sagração de Urubutsin. Fotos: Zulú Aborígene

Neste momento, aproximo-me destas questões a partir de um outro paradigma; o da abjeção. Ligado a concepçóes como nojo, rejeição, exclusão, expurgação, trauma, inferioridade, opressáo, horror e choque, o conceito de abjeto tem grande proximidade com questôes estéticas e artísticas. Apesar da centralidade de categorias como o belo ou sublime na história da filosofia estética ocidental, a experiência do nojo é apontada por 
15. MENNINGHAUS, Winfried. Disgust: The Theory and History of a Strong Sensation, 2003.

16. HOUSER, Craig et al. Abject Art, 1993.

17. SANTOS, Matheus. Imagem-abjeto: um estudo sobre manifestaçôes estéticas da abjeção, 2013.

18. BUTLER, Judith. Marcos de Guerra: Las Vidas Lloradas, 2010.

19. BATAILLE, Georges.

"L'Abjection et les Formes Misérables", 1970.

20. FABIÃO, Eleonora.

"Performance e teatro: poéticas e políticas da cena contemporânea”, 2009, p.235246.
Menninghaus ${ }^{15}$ como uma possibilidade de aproximação da esfera do sensível a partir deste lugar "negativo".

As manifestaçôes estéticas do abjeto são abundantes nas artes. Especialmente a partir dos anos de 1990, o conceito é amplamente requisitado pela crítica e pelos próprios artistas ${ }^{16}$. Nota-se, ao menos, duas maneiras pelas quais o conceito vem à tona neste campo $^{17}$. A primeira diz respeito à utilização de materiais "abjetos" por artistas que, através de investigaçóes com pêlos, sangue menstrual, fezes, urina, animais mortos, cadáveres humanos, vegetais em decomposição e outros excrementos, trazem o questionamentos sobre o corpo, a humanidade das coisas, sexualidade, gênero, raça e outros fenômenos que digam respeito à exclusão social e à abjeção de determinados grupos.

A outra maneira trata de pensar o abjeto tomando o seu caráter performativo, evidenciando o modo como o conceito está relacionado à construção de corpos marginais a partir da repetição e da citação de modos de ser. Creio que o trabalho de Sara e Filipe se aproxima dos problemas da abjeção pelas duas vias, tanto pela exploraçáo da carne e do sangue, como a partir de uma dimensão performativa.

A imagem de Sara banhada em sangue nos deixa diante da imensa fragilidade humana. Vemos seu sangue escorrer e temer pela sua vida é quase inevitável. $\mathrm{Na}$ medida em que se deixa tomar pelo líquido, Sara invoca as vidas precárias e suas condições cruéis de existência ${ }^{18}$. Um comum possível pela experiência da injúria, das vidas menosprezadas e marcadas pelo estigma da inferioridade mas que, segundo Georges Bataille ${ }^{19}$, carregam toda possibilidade de transgressão exatamente por estarem situadas "abaixo", compondo o excesso da civilização.

Por outro lado, é através de uma ação (e não apenas da materialidade do sangue) que ela apresenta o lugar da abjeção como potência criativa. Se ela deixa o seu corpo ser perfurado é menos para destruí-lo do que para construir um corpo ainda mais potente, fazendo do lugar do horror um espaço onde pode se dar o novo.

Se estes dois modos de aproximação do abjeto tratam-no como um problema de imanência, há também um aspecto transcendente que lhe diz respeito e que é invocado no trabalho dos dois - especialmente através da experimentação de estados psicofísicos alterados, que também caracterizariam a potência da performance ${ }^{20}$.

Se, em nossos dias, o termo "abjeção" remete ao pior da pornografia através das práticas sexuais ligadas à fetichizaçấo da urina, das matérias fecais, do vômito ou das secreçôes corporais, ou ainda a uma corrupção de todas as interdiçôes, ele não é dissociável, na cultura judaico-cristá, de sua outra faceta: a aspiraçáo à santidade. Entre o enrai- 
zamento na conspurcação e a elevação ao que os alquimistas chamavam outrora de "volátil", em suma, entre as substâncias inferiores - do baixo-ventre e do monturo - e as superiores - exaltação, glória, superação de si -, existe portanto uma estranha proximidade, feita de renegação, clivagem, repulsa, atraçãa ${ }^{21}$.

Os exemplos desta passagem do abjeto ao sublime através da degeneração, da dilaceração, da imersão no baixo e no sujo são fartos nas histórias bíblicas e nas posteriores trajetórias rumo à santidade. A história de Jó, objeto de aposta entre Deus e o Diabo, é um dos grandes exemplos inspiradores dos mártires do cristianismo por afirmar que "a salvação do homem reside na aceitação de um sofrimento incondicional" 22 .

Esta tentativa de identificaçáo com a Paixão de Cristo através da imolação corporal é ainda comum em diversas correntes da Igreja Católica que praticam o autoflagelo como puniçáo por seus pecados e também como uma busca de ascensão espiritual. No entanto, foi em épocas anteriores, nas quais a medicina não tinha o poder que possui atualmente e as vidas e mortes eram creditadas exclusivamente às vontades divinas, que estas "práticas de emporcalhamento e autodestruição" eram mais comuns.

Catarina de Siena, canonizada em 1461, afirmou jamais ter comido "nada táo delicioso quanto o pus dos seios de uma cancerosa", o que lhe permitiu escutar a voz de Deus através de uma descida extrema às impurezas materiais. Marguerite-Marie Alacoque, famosa por seus êxtases místicos na segunda metade do século XVII, ao escutar o chamado de Jesus "só conseguiu limpar o vômito de uma doente transformando-o em sua comida. Mais tarde, sorveu as matérias fecais de uma disentérica declarando que aquele contato bucal suscitava nela uma visão de Cristo mantendo-a com a boca colada em sua chaga"23.

Se utilizo estes exemplos é apenas para sinalizar que a aproximação transcendental da abjeção é de longa data. No entanto, é necessário chamar a atenção para uma diferença fundamental entre eles e as açôes de Sara e Filipe. Quando os mártires cristãos se aproximam desta "estética do abjeto", há a clara intençáo de busca por salvação a partir de um lugar de inferioridade marcado pela resignação. As experiências de êxtase atingidas pelos artistas nas performances em nada se assemelham a este lugar de subjugação. Pelo contrário, ao experimentar estas alteraçôes psicofísicas a partir da perfuraçáo corporal e do contato com o sangue, creio que o que se opera é exatamente a construção de linhas de fuga ${ }^{24}$. Trata-se de um movimento de descolonização corporal que, segundo Gómez-Peńa seria a última meta da performance: "hacer evidentes estos mecanismos descolonizadores ante el público, con la esperanza de que ellos se inspiren y hagan lo mismo por su cuenta"25.
21. ROUDINESCO. Elisabeth. "O Sublime e o Abjeto", 2008, p. 18.

22. Ibidem, p. 19.

23. Ibidem, p. 25.

24. GUATTARI, Félix. Lineas de Fuga: Por otro mundo de posibles. 2013.

25. GÓMEZ-PEÑA, Guillermo. "En defensa del arte del performance", 2005, p. 205. 
27. LAURETIS, Teresa De. "A tecnologia do gênero", 1994, p. 206-242.

28. HARAWAY, Donna. "Um manifesto para os cyborgs", 1994.

29. BUTLER, Judith. Gender Trouble. Feminism and the Subversion of Identity, 2006.
A performance deve ser tomada como um acontecimento ou, ao menos, como uma de suas formas de efetuação. Uma ação faz e desfaz temporalidades e espacialidades, promove conexóes intermitentes entre corpos e singularidades, conecta pontos ainda desencontrados para separá-los mais adiante, está aberta ao outro, ao imprevisto, ao que todavia não está dado.

Conversávamos sobre estas questóes, eu, Sara e Filipe, enquanto íamos em direção à Lapa, onde acontecia um festival ${ }^{26}$ do qual eles participariam com Pérolas aos Porcos. Eu, além de acompanhá-los como amigo, tinha também a função de registrar a ação com uma câmera de vídeo que havíamos conseguido poucas horas antes. A conversa chegara neste ponto porque os dois me contavam que o trabalho havia sido deformado devido às impressóes de um amigo. Percepçóes fortes o suficiente para fazê-los decidir por algo distinto. Um último movimento, ainda inédito, seria executado neste dia. Eu estava ansioso por vê-lo.

No fundo da sala Filipe permanece em pé ao lado de uma mesa com o material de perfuração e as pérolas que utilizará mais adiante. Ele veste luvas cirúrgicas, uma saia que vai até seus pés, um lori lori e uma máscara branca com o nariz bastante alongado, feita a partir do molde do seu próprio rosto. Sara entra pelo lado oposto da sala, usando apenas uma micro calcinha preta e saltos altos da mesma cor. Seus olhos sustentam longos cílios postiços e alguma maquiagem.

Vejo através da tela da câmera. Com o zoom consigo chegar bem próximo aos detalhes. Recorto imagens, compondo outras. Percebo o andar tortuoso de Sara em direção a Filipe; um certo desconforto no seu caminhar, que me parece quase robótico. Vejo outra vez o salto alto. Possivelmente o fato de nunca ter visto Sara usá-los tenha me chamado tamanha atençáo. O corpo elevado, elegante. Os músculos tesos, a forma delineada, ideal.

Penso no salto como prótese a serviço das tecnologias de gênero ${ }^{27}$. A produçáo artificial de feminilidade que termina por questionar o conceito mesmo de humanidade; "Por que nossos corpos deveriam terminar na pele?", pergunta Haraway ${ }^{28}$. Penso no andar como ato performativo sustentado por sua citacionalidade e reiteração, como o faz Judith Butler ${ }^{29}$ a partir da revisão das teorias de J. L. Austin. A repetição contínua do andar. Um pé após o outro. Um salto após o outro. Repetição e diferença; o andar maquínico e inconstante de Sara não nos deixa esquecer. Ela segue vagarosamente em direção a Filipe. Neste momento o tempo parece se dilatar e percebo um público ansioso em relação à possibilidade do que está por vir.

Ao encontrar Filipe, Sara lhe dá as costas e se senta em um 
banco, levando ao colo uma pequena bacia. Ele, cuja figura me remete a uma mistura de cirurgião, titereiro e xamã, começa a manipular os seus aparelhos e as costas de Sara. De início, o olhar atento manuseia a pele, testando e estabelecendo limites, preparando-a para o atravessamento. Enquanto isso, Sara inicia um novo movimento e as pessoas na sala também se movem na tentativa de acompanhar a ação em todos os seus detalhes. Certamente, o ponto de vista é muito importante aqui.

Enquanto Filipe analisa suas costas, Sara leva a mão até a bacia, retirando dela uma substância branca e gosmenta que me lembra imediatamente sêmen. Sem se importar com o excesso que escorrega por seus dedos sujando o piso e respingando em seu corpo, ela leva a mão à boca, enchendo-a com a gosma informe e deixando que seu corpo seja tomado pelos restos que dela caem.

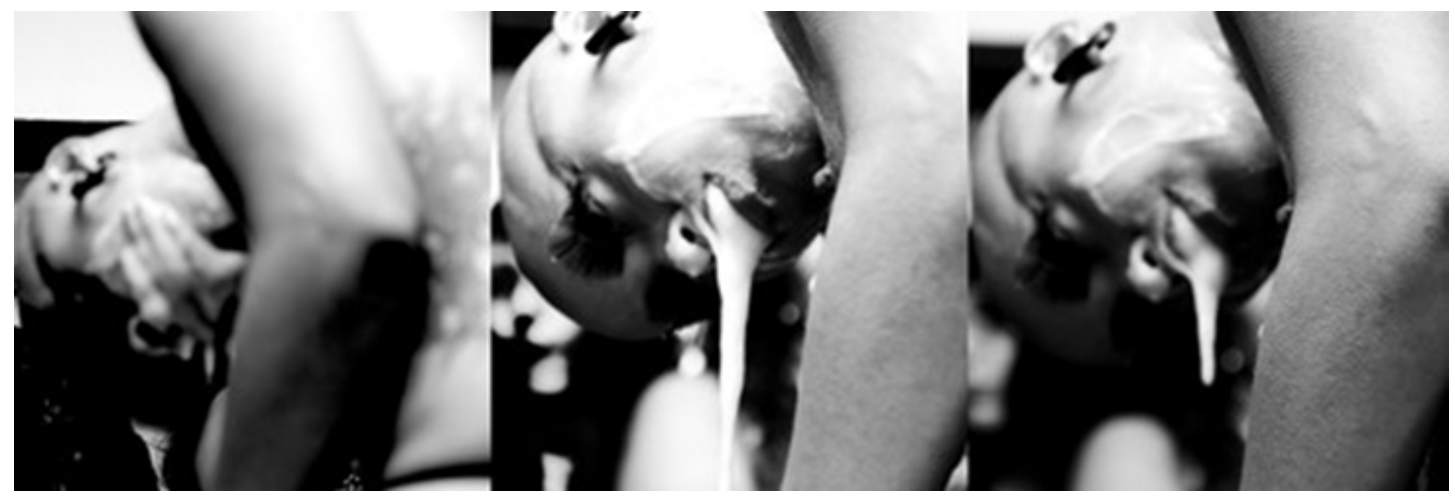

Fig. 05: Pérolas aos Porcos. Foto: Pedro Spagnol

Filipe segue a sua ação. Com linha e agulha, começa a costurar pérolas no corpo que manipula. A primeira é costurada no lado superior das costas, próximo ao pescoço. Ele segue perfurando com precisão, formando uma linha de pérolas sobre a coluna vertebral de Sara. Muitas pessoas se aproximam e as reações são diversas; alguns expressam horror frente à pele perfurada, outros parecem fascinados com o que veem.

Sara segue comendo e cuspindo o "excremento". Não consigo afastar a ideia de que aquilo "seja" sêmen, creio que a tensão erótica e sexual da performance tenha me levado a esta leitura tâo imediata e estanque. Enquanto executa o movimento repetidamente, Sara tem uma expressão forte. Seus olhos parecem sempre fixos em algum ponto, ao mesmo tempo em que ela move a cabeça lentamente e, por vezes, pousa os olhos sobre alguém na sala. Em dado momento, após encher a mão na bacia, ela a estende para frente, como que oferecendo a alguém. Imediatamente uma mulher se aproxima e toma a gosma de suas mãos, levando-a também à boca. Não demora muito para que mais pessoas componham a açáo e experimentem a substância de variadas formas. 
Filipe termina o seu trabalho; cerca de 20 pérolas compóem a coluna vertebral exterior de Sara. Ela se levanta. Ele tira suas luvas e também sua saia. É notável a expressão de surpresa das pessoas que vêem o seu corpo nu pela primeira vez, especialmente o seu saco escrotal ostentando 13 piercings. E é a ele mesmo que se dirige Sara, que, com a ajuda de uma corda, o amarra e outra vez volta a andar. Desta vez puxando a corda com as duas mãos e arrastando Filipe pelo saco até deixarem o espaço pela mesma porta pela qual ela havia entrado no início.

Se insisto neste último relato é porque acredito que ele invoca, de modo bastante claro, as questóes apresentadas até aqui: Os artistas que constroem para si corpos através do processo de colagem e sobreposição de imagens; a modificação corporal utilizada em cena como experiência do corpolimite em direção a uma poética em carne-viva; a força da presença em detrimento da codificação representacional; a possibilidade de estéticas abjetas ligadas mais à criação que a niilismos destrutivos; e, principalmente, as relaçóes compostas entre os artistas e as potências efetuadas a partir deste encontro.

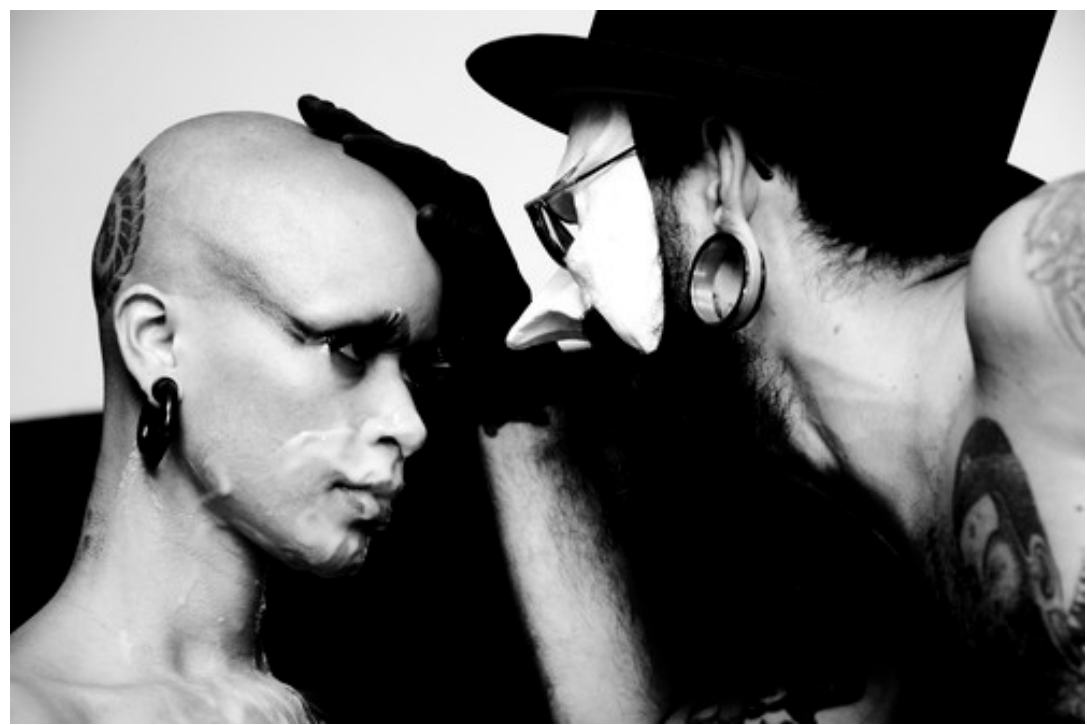

Fig. 06: Pérolas aos Porcos. Foto: Pedro Spagnol 


\section{Referências}

BATAILLE, Georges. "L'Abjection et les Formes Misérables". In:__. Essais de Sociologie: Oeuvres Complètes, Vol.2.

Paris: Gallimard, 1970.

BOURRIAUD, Nicolas. Estética Relacional. São Paulo: Ed.

Martins Fontes, 2009.

BUTLER, Judith. Marcos de Guerra: Las Vidas Lloradas.

Buenos Aires: Paidós, 2010.

Gender Trouble. Feminism and the Subversion of

Identity. 3 ed. New York: Routledge, 2006.

DELEUZE, Gilles. En medio de Spinoza. Buenos Aires: Cactus, 2013.

FABIÃO, Eleonora. "Performance e teatro: poéticas e políticas da cena contemporânea”. Revista Sala Preta. São Paulo, p. 235246, 2009.

GÓMEZ-PEÑA, Guillermo. "En defensa del arte del performance". Horiz. antropol. vol.11, n.24, p. 199-226, 2005.

GUATTARI, Félix. Lineas de Fuga: Por otro mundo de posibles. Buenos Aires: Cactus, 2013.

GUMBRECHT, Hans Ulrich. Produção de Presença: o que o sentido não consegue produzir. Rio de Janeiro: Contraponto, 2011.

HARAWAY, Donna. "Um manifesto para os cyborgs: ciência, tecnologia e feminismo socialista na década de 80". In: BUARQUE DE HOLLANDA, Heloísa (Org.), Tendências e impasses: o feminismo como crítica da cultura. Rio de Janeiro: Ed. Rocco, 1994.

HOUSER, Craig et al. Abject Art: Repulsion and Desire in America Art. New York: ISP Paper, 1993.

LAURETIS, Teresa De. "A tecnologia do gênero". Tradução de Suzana Funck. In: BUARQUE DE HOLLANDA, Heloisa (Org.). Tendências e impasses: o feminismo como crítica da cultura. Rio de Janeiro: Rocco, 1994, p. 206-242.

MENNINGHAUS, Winfried. Disgust: The Theory and History of a Strong Sensation. Albany: Suny Press, 2003.

MUSAFAR, Fakir. "Entrevista". Modern Primitives: 20th anniversary deluxe edition, 1989. 
PANAMBY, Sara. O Corpo-limite. Dissertação de mestrado, 2013a.

"Compassos do Ocaso: An Experiential Re-telling". In: KEIDAN, Lois; WRIGHT, Aaron. (Org.). The Live Art Almanac. Volume 3. 1ed. Londres: Live Art Development Agency and Oberon Books, 2013b, v. 1.

ROUDINESCO. Elisabeth. O Sublime e o Abjeto. In: A Parte Obscura de Nós Mesmos. Rio de Janeiro: Jorge Zahar, 2008.

SANTOS, Matheus. Imagem-abjeto: um estudo sobre manifestaçôes estéticas da abjeção. Dissertação de mestrado, ECO-Pós/UFRJ, 2013. 